\title{
Design Tool Study Case Methods on a Course of Natural Science
}

\author{
$1^{\text {st }}$ Lala Jelita Ananda ${ }^{1}, 2^{\text {nd }}$ Lidia Simanihuruk $^{2}, 3^{\text {rd }}$ Imelda Free Unita Manurung ${ }^{3}$ \\ \{ljananda.84@gmail.com 1 \}
}

Elementary School Teacher Education Department of Faculty of Education, Universitas Negeri Medan, Indonesia ${ }^{1,2,3}$

\begin{abstract}
This research is a development research that aims to produce a product in the form of Case Method-Based Online Learning Devices in Elementary Science Learning Courses at Unimed Elementary School Teacher^s Study Program. The Learning Tools consist of: Semester Learning Plans (RPS), Lecture Program Units (SAP), Student Worksheets (LKM), Assessment Instruments and Teaching Materials. Based on literature and field studies, in the early stages a draft of the Case Method-Based Online Learning Tool was produced for Elementary Science subjects. In the next stage, the resulting product is developed through validity, practicality, and effectiveness tests. At this stage, the learning tools developed are reflected and revised according to the needs of lecturers and students based on the trials carried out. The development of this learning device is carried out using a 4 (four) D development model (Define, Design, Develop, and Disseminate) which focuses on the needs of lecturers and students. At the initial stage, needs analysis, concept analysis, and analysis of Elementary School Teacher^s Education students were carried out. Based on this analysis, a Case Method-Based Online Learning Tool was designed for Elementary Science Learning Courses at PGSD FIP UNIMED. Products that have been The results are then revised based on expert tests, small group tests, and test field. At the end, evaluation and dissemination are carried out to test the effectiveness the resulting product. Thus, this development research will produce Case Method-Based Online Learning Tools in Elementary Science Learning Courses that are valid, practical, and effective. The outputs that will be produced in this research to be carried out. These are: 1) Case Method-Based Online Learning Devices for Elementary Science Learning Courses at Unimed PGSD Study Program. The Learning Tools consist of Semester Learning Plans (RPS), Lecture Program Units (SAP), Student Worksheets (LKM), and Assessment Instruments- 2).
\end{abstract}

Keywords: Online learning devices, Case Mehod, Elementary Science learning.

\section{Introduction}

The Natural Science Learning course in Elementary School is one of the subjects taught in the Elementary School Teacher Education Study Program, Faculty of Education, Universias Negeri Medan. The learning objective of this course is to provide experience for prospective elementary school teacher students in designing natural science lessons in elementary schools. So far what has happened in the lecture process, the learning process has not focused on solving problems in the field such as learning problems in elementary schools. In the lecture process, students still focus on discussing natural science material, and very rarely focus on solving natural science learning problems for elementary school students. This problem is the focus of this research. 
One of the learning methods that apply case solving in it is the Case Method learning method. The academic background of this learning method is to close the distance between students and the real world that they will meet after graduating from college. Case-Based Reasoning is an approach to problem solving by emphasizing the role of previous experience. New problems can be solved by reusing and perhaps making adjustments to problems that have similarities that have been solved previously.

Currently, the learning process throughout Indonesia, especially at the Universitas Negeri Medan is carried out intact in the network due to the impact of the Covid-19 pandemic. Massive social restrictions were carried out to prevent the spread of Covid-19, such as meetings in the classroom that were turned into whole online learning. This is also a problem for lecturers to solve immediately.

Efforts to solve some of the problems above are to prepare online learning tools based on Case Method in Elementary Science Learning Courses. In this case, it is designing a Case Method-based learning device in the Elementary Science Learning course that will be used for online learning. The learning tools consist of Semester Learning Plans, Lecture Contracts, Teaching Materials, Student Worksheets, and Assessments which as a whole can be accessed by students independently on the network anytime and anywhere. Based on the explanation above, researchers are interested in conducting research with the title "Design of Case Method-Based Online Learning Devices in Natural Science Learning Courses in Elementary School of PGSD FIP UNIMED.

\section{Method}

This research was conducted at the Elementary School Teacher Education Study Program, Faculty of Education, Universitas Negeri Medan for students in the third semester of the 2021/2022 academic year. This research is a type of research and development using 4D models. The 4D development model consists of 4 stages, namely: 1) Define, 2) Design, 3) Develop, and 4) Dessiminate. The development procedure in this study was carried out through the following stages:

\subsection{Defining Stage}

At this stage there are three stages of activities, namely curriculum analysis, concept analysis and student analysis.

a. At the stage of curriculum analysis, an analysis of course learning outcomes is carried out based on the Indonesian National Qualifications Framework curriculum.

b. Concept analysis is carried out to find out the main concepts that must be mastered by students in the Natural Science Learning Course in Elementary School.

c. At this stage an analysis is carried out to determine the characteristics of students such as age, motivation, different educational and educational backgrounds, academic abilities, and social skills..

\subsection{Design Stage}

This stage aims to design an online learning device based on the Case Method in Natural Science Learning Courses in Elementary Schools. Based on the concept analysis that has been carried out in the Definition Phase, learning tools designed are the semester learning 
implementation plan, the Lecture Program Units, Student Worksheets, and Case Methodbased Assessment Instruments.

\subsection{Development Stage}

This stage is carried out with the aim of producing a Case Method-based online learning tool in Science Learning Courses in Elementary Schools that is valid, practical, and effective. This stage includes validity test, practicality test, and effectiveness test. Validitiy test means an online learning device based on Case Method in Science Learning Courses in elementary schools that is designed to be validated by an expert validator according to his field of expertise. While practicality means that after the validity test stage, it is revised and then tested during lectures to find out the practicality of learning tools. Practicality is the level of practicality of Case Method-based online learning tools in Science Subjects in Elementary Schools, when used in the learning process, while effectiveness is an assessment of the effectiveness is an assessment of the effectiveness aspects of Case Method-based online learning tools in Science Learning Courses in Elementary Schools, in the form of Cognitive evaluation results, namely the results of student learning tests and student activities during the learning process.

\subsection{Dessiminate Stage}

The Dessiminate phase aims to promote the development product so that it can be accepted by users, whether individuals, groups or systems. At this stage, the product is distributed on a wider scale. Data collection techniques in this study are as follows:

a. Validation is carried out on 2 aspects, namely content validation and construct validation. Data were collected using a validation sheet.

b. Observations were made to observe the implementation of the developed learning tools. Data were collected using observation sheets.

c. Questionnaire sheets were used to collect information related to the responses of lecturers and students to the developed learning tools.

d. Interviews are used for supporting data in measuring the level of the practicality and effectiveness of the developed learning tools. The instrument used is an interview guide.

Data analysis techniques used in this study is a quantitative and qualitative descriptive data analysis. The expert test and small group test data from the questionnaire were analyzed by percentage and explained qualitatively. Field test/ user test data in the form of learning processes in the development environment were analyzed by qualitative data analysis of flow models by applying the multipurpose principle. In this case what is important is how an analytical technique can be used to support problem solving.

Analytical activities, including: data reduction, data presentation, and retrieval conclusion or verification. Data reduction activities include classifying and coding according to the type of data. Presentation of data in the form of a description descriptions, tables, diagrams, pictures or other visual forms. Data already presented is verified, interpreted, and concluded. Data analysis targets include observation, description, and explanatory levels. At the observation level the data is selected, categorized, and coded. At the description level, the data is presented in patterns, events, tendencies, or meaning units. At the explanatory level, the analysis is directed at the effectiveness of the trial. 


\section{Results and Discussion}

In this study, the Development of Case Method-Based Online Learning Device Design for Natural Science Learning Courses in Elementary Schools in Elementary School Teacher Education Study Programs was carried out. This development research uses a 4D model (fourD models) which consists of 4 main stages, namely: 1) Define (determine the material), 2) Design, 3) Develop, and 4) dessiminate. In this article, the stages are carried out up to the design of learning device designs based on the results of curriculum analysis and student characteristics of the Elementary School Teacher Education study program.

The Design Process for Case Method-Based Online Learning Devices in Natural Science Learning Courses in Elementary Schools is as follows:

\subsection{Defining Stage}

At this stage, an analysis of learning objectives and teaching materials is carried out in the Natural Sciences Learning course in Elementary School. The analysis was carried out based on the need for mastery of the concept of Natural Science Learning in elementary schools at the level of undergraduate students of the Elementary School Teacher Education Study Program. From the results of this analysis obtained 11 (eleven) subject matter in the Natural Science Learning course in Elementary School with each different learning objectives. Learning Objectives are designed based on the Case Method in accordance with the learning outcomes set in the Primary School Teacher Education study program.

\subsection{Design Stage}

At this stage, the Design of Case Method-Based Online Learning Devices is carried out in Natural Science Learning Courses in Elementary Schools. The device design is arranged based on the Case Method which will be used for online learning.

\section{Conclusion}

In this study, the Development of Case Method-Based Online Learning Device Design for Natural Science Learning Courses in Elementary Schools in Elementary School Teacher Education Study Programs was carried out. This development research uses a 4D model (fourD models) which consists of 4 main stages, namely: 1) define (determine the material), 2) design (design), 3) develop (development), and 4) dessiminate (dissemination). . In this article, the stages are carried out up to the design of learning device designs based on the results of curriculum analysis and student characteristics of the Elementary School Teacher Education study program. The design of learning devices is arranged based on the Case Method which is adjusted to the learning achievements of Elementary School Teacher Education Students.

\section{References}

[1] Andi Prastowo. 2013. Panduan Kreatif Membuat Bahan Ajar Inovatif. Yogyakarta: Diva Press

[2] Arsyad, A. 2013. Media Pembelajaran. Jakarta: PT. Raja Grafindo Persada. 
[3] Arum \& Minangwati. 2014 Penerapan Metode Pembelajaran Studi Kasus Berbantuan Modul untuk Meningkatkan Keterampilan Berpikir Kritis. Jurnal Chemistry in Education, Oktober

[4] Lembaga Penelitian dan Pengabdian kepada Masyarakat Unimed. 2021. Panduan Pelaksanaan Penelitian dan Pengabdian Kepada Masyarakat. Medan: LPPM Unimed.

[5] Sugiyono. 2015. Metode Penelitian Kuantitatif, Kualitatif dan R\&D. Bandung: Alfabeta

[6] Sukmadinata, N \& Syaodih. 2012. Kurikulum \& Pembelajaran Kompetensi. Bandung: Refika Aditama.

[7] Zuhdan, K. P, dkk. 2011. Pengembangan Perangkat Pembelajaran Sains Terpadu untuk Meningkatkan Kognitif, Keterampilan Proses, Kreativitas serta Menerapkan Konsep Ilmiah Peserta Didik SMP. Yogyakarta: Pascasarjana Universitas Negeri Yogyakarta. 